\title{
Sylwia Rynkiewicz
}

Uniwersytet Papieski Jana Pawła II w Krakowie

\author{
PIERWSZE SPOJRZENIE. SPRAWOZDANIE \\ Z KONFERENCJI \\ „DUSZĘ DAĆ TRZEBA. PRACA SOCJALNA W ŚWIETLE \\ FILOZOFII SPOTKANIA" \\ (Kraków, 14-15 listopada 2016)
}

\begin{abstract}
The first look. Report from the conference "Let the Soul be given. Social work in the light of philosophy of dialogue" (Cracow, 14 -15 November 2016)

I have known as much as I was given to know, at the same time it was as much as I needed and enough to satisfy my curiosity. I do not like complaining, so I am glad I did not have to. This was the first conference I attended, during which the lecturers and speakers were not disturbed by others because they talked longer than it was planned. The organizers have shown how important a person is, and how valuable is His work, knowledge and presence; for all of which I would like to express my gratitude.
\end{abstract}

Key words: philosophy of dialogue, social work, the participant's perspective on a conference

Choć często wydawać by się mogło, że studenci mają alergię na słowa „konferencja naukowa", to ciekawe jest doświadczyć, że nie musi tak być. Pamiętam, kiedy wykładowcy mówili nam o organizowanej konferencji, na której „obecność jest obowiązkowa”. To błąd, który powoduje, że na takich spotkaniach pojawiają się ludzie niezainteresowani jego tematyką, nerwowo patrząc na zegarek, nie angażują się w jego przebieg. O ile ciekawsze i ubogacające jest spotkanie, na które decydujemy się świadomie i dobrowolnie? Miałam okazję przekonać się o tym poprzez uczestnictwo, także od kuchni, w konferencji pod hasłem: Duszę dać trzeba. Praca socjalna w świetle filozofi spotkania.

Podczas spotkania organizacyjnego zobaczyłam złożoność i ogrom pracy, jakiej wymaga zaplanowanie każdej godziny spotkania, a przecież zadanie na samym planowaniu się nie kończy. Niezwykle istotne było współdziałanie wykładowców, osób praktykujących już zawód pracownika socjalnego ze studentami. Ta owocna współpraca, przebiegająca w atmosferze wzajemnego szacunku i zrozumienia, sprawiła, że konferencja była atrakcyjna dla osób w każdym wieku bez względu na poziom wykształcenia. Na spotkaniu od razu rzucała się w oczy ogromna dbałość o szczegóły - od wyglądu identyfikatorów do rozmieszczenia plakatów, od odległości wieszaków od ściany do ustawienia kosza 
na parasole. Analizowano drogę uczestników od recepcji do auli, na której miała się odbywać konferencja. Rola każdego została omówiona, wielokrotnie podkreślano, że nie ma tu osób niepotrzebnych. Atmosfera była przyjazna, był czas na żarty, był czas na pytania, przez - co w moim odczuciu - każdy czuł się dobrze i wiedział, co do niego należy. Ja, jako osoba „Z zewnątrz”, również nie poczułam się pominięta, otrzymałam odpowiedzi na każde pytanie, które zadałam. Nie było osoby, która odmówiła mi pomocy w zbieraniu materiałów. Poznałam tyle, ile dano mi poznać, jednocześnie było to tyle, ile potrzebowałam i ile wystarczało, by zaspokoić moją ciekawość. Nie lubię pisać o kimś źle, dlatego cieszę się, że tutaj nie musiałam.

Pierwszego dnia konferencji już od ósmej rano mogłam ponownie przyglądać się pracy organizatorów. Profesor Hubert Kaszyński, który był jednocześnie organizatorem i moderatorem spotkania, zarządzał pracami, by nie wprowadzać niepotrzebnego zamieszania. Na początku wydawało mi się, że wszyscy schowali nerwy do kieszeni, jednak im bliżej była dziewiąta trzydzieści, tym bardziej dostrzegałam, że pełny spokój i opanowanie to tylko pozory. Studentki mające rozpocząć sesję studencką próbowały napięcie rozchodzić, powtarzały to, co chciały powiedzieć na otwarciu. Był nawet czas na krótkie rozluźnienie, w rytmach muzyki Krzysztofa Krawczyka. Jakkolwiek to zabrzmi, mnie ten stres urzekł. Zobaczyłam, jak poważnie dziewczyny traktują swoje role, jak bardzo zależy im, by wszystko się udało. To zaangażowanie było wyrazem poczucia odpowiedzialności za grupę i za to, by te wszystkie tryby, które omawiano na spotkaniach organizacyjnych, współdziałały, by każdy element był godny następnego. Przed samym rozpoczęciem sesji również ja otrzymałam swój identyfikator „Komitetu Organizacji Konferencji”, co było dla mnie bardzo miłym gestem, poczułam się maleńką częścią tego przedsięwzięcia.

Spodobało mi się ułożenie krzeseł w formie okręgu. Sprzyjało to integracji i przełamaniu dystansu między uczestnikami spotkania. W rogu sali przygotowane były ładnie zapakowane chlebki, które miały być upominkiem dla uczestników konferencji. Dzięki nim w całym pomieszczeniu unosił się zapach świeżego pieczywa, co tworzyło niepowtarzalny klimat. Gdy wybiła dziewiąta trzydzieści, rozpoczęła się sesja dyskusyjna. Gośćmi honorowymi byli pan Wacław i pan Aleksander, dwaj niezwykli mężczyźni, którzy doświadczyli bezdomności i którzy dziś wrócili do „normalności” życia w społeczeństwie. Dziewczyny rozpoczęły spotkanie, snując refleksję nad tym, kim jest osoba bezdomna prawnie, a kim w odczuciu społecznym. Czym jest dom - czy tylko murami, czy może czymś więcej, osobami, które go tworzą? Jak stwierdziły, bezdomność ma wiele twarzy, a jedne $\mathrm{z}$ nich prezentują przybyli goście.

Od swojej historii zaczął pan Aleksander, przyjaciel pana Wacława. Opowiadał o swoim dzieciństwie, o kompleksach, poczuciu samotności, smutku i tęsknocie za miłością, a także o momentach, kiedy zastanawiał się, czy jest jeszcze osoba, dla której jest ważny. W tej całej rozpaczy sięgnął po alkohol, który w tamtym czasie wydawał mu się wybawcą od codziennych trosk. Jego relacje rodzinne zaczęly się sypać. Pan Aleksander wyprowadził się z domu. Zaczął się tułać, trafiał od przytułku do przytułku. Utkwiło mi w pamięci to, co nasz gość mówił, że miał wtedy poczucie bycia lepszym, bo alkohol sprawia, że nawet człowiek, który leży pijany na ulicy, potrafi patrzyć na przechodniów 
z góry. Będąc w przytułku, pan Aleksander czuł się tak samo wobec ludzi, którzy tam z nim przebywali. Dopiero z czasem dostrzegł w każdej z tych osób człowieka, widział ich talenty, do muzyki czy choćby do języków. Jak powiedział pan Aleksander: „Od tego czasu, już nie lekceważę żadnego człowieka”. Po piętnastu latach tułaczki mężczyzna stanął na nogi, między innymi dzięki wspaniałym ludziom, których spotkał na swojej drodze. Jak mówił, nie miał pretensji do Pana Boga ani do nikogo innego, a „bezdomność wyleczyła go z egoizmu”. Dziś skończył studia, ma wspaniałą żonę, dwójkę dzieci na ziemi i dwójkę w niebie - podkreśla, że jest szczęśliwy. Kiedy słuchałam jego historii, nie mogłam wyjść z podziwu, że człowiek, który tak wiele przeszedł, potrafi tak często żartować i tak dużo się uśmiechać. Myślę, że każdy z nas mógłby się od niego wiele nauczyć. Na zakończenie swojej wypowiedzi pan Aleksander podarował nam dwa chleby, które upiekł ze swoimi kolegami w piekarni, w której niegdyś pracował, przez dwanaście lat. Był to piękny gest, zwłaszcza że patronem naszego spotkania był św. Brat Albert.

Pan Wacław również zrobił na mnie nie mniejsze wrażenie. Przede wszystkim swoją skromnością i pokorą, mówiąc, że nie czuje się gwiazdorem, dlatego opowiadając, chciał stać z szacunku do nas. Swoją historię rozpoczął od krótkiego wspomnienia dzieciństwa, kiedy był pełen kompleksów. Okres ten sprawił, że zatracił poczucie własnej wartości. Jak mówi: „Od kiedy pamiętam, to się bałem, nie wiem nawet czego, po prostu się bałem”. Pan Wacław podkreślił, że bezdomność nie zaczyna się na ulicy, ale że „bezdomność zaczyna się w sercu”. Potem, w dorosłym życiu, założył rodzinę, ale relacje w niej panujące nie były takie, jakich by pragnął. Alkohol zaczął kierować jego życiem. Mężczyzna, jak twierdzi, zaczął cierpieć na „raka duszy”. Tułał się przez dwadzieścia pięć lat, wiecznie będąc nieszczęśliwy. Któregoś dnia w jednym z przytułków, czekając trzy dni na wolne łóżko, zrozumiał, że jest w tym miejscu na własne życzenie. Wymagał od innych, sam nie wiele dając w zamian. Pan Wacław spotkał na swojej drodze ludzi, którym nie był obojętny. Dziś i on jest szczęśliwy, również skończył studia, odbudował relacje z rodziną i pracuje z dziećmi z trudną przeszłością. Piękne w tej wypowiedzi było to, że zakończył ją słowami: „A mówiłem już państwu, że państwa kocham?”. Było to niespodziewane i niezwykłe zwieńczenie tak ciężkiej, a zarazem cudownej, historii. Gdy patrzyłam na twarze słuchaczy, wszyscy zdawali się poruszeni, zarówno jedną, jak i drugą historią. Kiedy mężczyźni mówili, na sali panowała całkowita cisza. Każdy słuchał z uwagą i przejęciem. Co więcej, był też czas na pytania i refleksje, czas, który zdecydowanie został dobrze wykorzystany, zważywszy na to, że skończyliśmy dwadzieścia minut po planowanym czasie, a nikt nawet nie próbował wspomnieć o przerwie.

Kolejną częścią spotkania był spacer związany z postacią św. Brata Alberta. Były dwie możliwości: albo spacer na Skałkę i na ulicę Krakowską do Braci Albertynów, którzy kontynuują dzieło swojego założyciela, albo odwiedzenie Sanktuarium Ecce Homo i Sióstr Albertynek, aby lepiej poznać sylwetkę świętego. Ja miałam możliwość uczestniczenia w spacerze. Na Skałce jeden z Ojców Paulinów przybliżył nam historię św. Brata Alberta i jego związku ze Skałką. Oprowadził nas po terenie sanktuarium, pokazując miejsce słynnej ogrzewalni z końca XIX wieku, gdzie nastąpiło symboliczne spotkanie Adama Chmielowskiego (później św. Brata Alberta) z twarzą innego. Mieliśmy także okazję 
zwiedzić Kryptę Zasłużonych, gdzie pochowani są między innymi Czesław Miłosz, Jan Długosz i Adam Asnyk. Weszliśmy także do wnętrza Bazyliki św. Michała Archanioła. Mimo niskiej temperatury na zewnątrz otrzymaliśmy cenną lekcję historii. Potem udaliśmy się na ulicę Krakowską do Zgromadzenia Braci Albertynów. Po budynku oprowadził nas brat Paweł Flis, pokazał nam zarówno kilka oryginalnych, jak i kilka replik obrazów św. Brata Alberta znajdujących się na terenie Zgromadzenia. Bardzo ciekawie opowiedział nam o niezwykłej pracy Braci Albertynów, którzy służą bezdomnym i pomagają im odbić się od dna. Mogliśmy wiele zobaczyć, od kaplicy do stołówki, z której korzystają ubodzy. Działalność ta zdecydowanie inspiruje, jest tworzona przez ludzi i dla ludzi. Dla mnie to kolebka prawdziwego człowieczeństwa, które dziś czasami ciężko jest dostrzec w pędzącym nieustannie świecie.

Myślę, że na konferencję nie wróciliśmy zmęczeni mimo mrozu i dwugodzinnego spaceru, naładowaliśmy się pozytywną energią Braci Albertynów. Po powrocie na uczelnię był czas na obiad. Zaraz przy wejściu do budynku swoje stoisko miała Bonifraterska Fundacja Dobroczynna, która zachęcała do zakupu miodu, świec i soków, z których sprzedaży pieniądze przekazywane są na działalność fundacji, czyli pomoc potrzebującym.

Przed rozpoczęciem konferencji Ola, jedna ze studentek, częstowała uczestników chlebem. Był to piękny, symboliczny gest w duchu naszego spotkania. Działanie to spotkało się z bardzo pozytywnym odzewem przybyłych gości, którzy z uśmiechem przyjmowali podarunek. O godzinie szesnastej rozpoczęła się konferencja, niemal przy pełnej sali. Profesor Hubert Kaszyński wprowadził do niej, zachęcając, by na czas naszego spotkania, wyjść ze swoich ról społecznych, by „postarać się przez chwilę być bezdomnym", bo tylko wtedy nasze spotkanie spełni swoją funkcję. Oficjalnie spotkanie rozpoczął bp Grzegorz Ryś. Nawiązywał on do dzieła św. Karola Wojtyły Brat naszego Boga, a także do słów papieża Franciszka, byśmy nie bali się bliskości i dotknięcia drugiego człowieka. Potem kilka słów do zgromadzonych powiedziała pani minister Elżbieta Bojanowska. Mówiła o odpowiedzialności w pracy socjalnej, odpowiedzialności, która spoczywa na barkach zarówno pomagającego, jak i tego, który tę pomoc otrzymuje. Swoją wypowiedź zakończyła zachętą do tego, by nie bać się pomagać drugiemu człowiekowi. Kilka słów do zgromadzonych powiedział także ks. profesor Piotr Kroczek, który mówił o pojmowaniu filozofii spotkania. Wyraził także nadzieję, że św. Brat Albert jest dziś pośród nas.

Po tych pięknych słowach wstępu mogliśmy posłuchać trzech niezwykle ciekawych, ale i zupełnie różnych, wykładów. Pierwszy pod tytułem Personalistyczne troski o drugiego wygłosił o. profesor Jarosław Kupczak. Mówił on o tym, że należy odróżnić ludzi od rzeczy, bo to zmienia całe spojrzenie i podejście do drugiej osoby. Człowiek nie może być naszym środkiem do celu, bo wartość człowieka nie jest utylitarna ani redukowalna. W swojej wypowiedzi o. profesor Kupczak wielokrotnie odwoływał się do nauki św. Jana Pawła II czy do słów ks. Józefa Tischnera, ale także do nauk biblijnych. Jak mówił, „poznanie człowieka, jest dojrzałością człowieka poznającego”, wymaga od nas otwarcia, szczerości, szacunku oraz budowania atmosfery bezpieczeństwa i zaufania. Wykład - choć może trudny i filozoficzny - miał ogromnie ważny przekaz. Każdy mógł 
w duchu zrobić sobie rachunek sumienia, jak on sam patrzy na drugą osobę, czy jest to spojrzenie podmiotowe, czy przedmiotowe?

Kolejny wykład należał do profesor Małgorzaty Opoczyńskiej-Morasiewicz. Nosił on tytuł Między darowaniem sobie a darem dla drugiego. O sztuce pomagania refleksji kilka. Był to wykład niezwykle refleksyjny, wprawiający w zadumę, przenoszący nas do świata poezji, która niejako zderza się z rzeczywistością. Pani profesor zastanawiała się, dlaczego pomoc nie zawsze staje się darem, jaki wpływ na to, jak patrzymy na tę samą rzecz, ma przebyta przez nas droga. Czasem patrzymy na to samo, ale ma to dla nas inną wartość, bo wynika z naszej różnorodności doświadczeń. Co możemy wiedzieć o drugim człowieku, nie będąc nim? To bardzo ważne pytanie i warto sobie w duchu na nie odpowiedzieć. Mnie ten wykład skojarzył się z powiedzeniem „Zanim zaczniesz kogoś oceniać, włóż jego buty i przejdź jego drogę". Niestety, nie wiem, czyje to słowa, ale to właśnie je mam w głowie, przywołując w myślach wykład pani profesor.

Po półgodzinnej przerwie nastał czas na ostatni wykład, wygłoszony przez profesora Tomasza Biernata Wiara, nadzieja i miłość jako aksjologiczna przestrzeń spotkania w pracy socjalnej. Wykład ten był bardzo obrazowy - dosłownie. Było to spotkanie z dziełami malarskimi jako portretami wartości (wiara, nadzieja, miłość). Każda z tych wartości znalazła odzwierciedlenie na płótnie. Osobowość profesora Biernata, jego naturalność i skromność sprawiły, że wykład ten zapamiętam. Obserwując skupione i jednocześnie uśmiechnięte twarze, mogę stwierdzić, że profesor bez trudu zjednał sobie publiczność. Był to doskonały moment do otwarcia przestrzeni refleksji. Rozpoczą ją profesor Krzysztof Frysztacki wraz z profesor Katarzyną Ornacką. Potem wypowiedzieć się mógł każdy z uczestników, każdy, kto miał na to ochotę. Mogło to być zarówno pytanie, jak i refleksja. To był czas słuchaczy. Cieszył fakt, że nie było dłuższych momentów ciszy. Zgromadzeni chcieli mówić, chcieli wyrażać swoje odczucia i wrażenia. Było to ciekawe doświadczenie, zwłaszcza że często - gdy uczestniczyłam w innych konferencjach - kiedy był czas na dyskusję, trzeba było prosić publiczność o zabieranie głosu. Jeśli już ktoś zdecydował się mówić, zwykle byli to wykładowcy, bardzo rzadko studenci. Tutaj była bardzo duża różnorodność osób wypowiadających się, był to temat, który łączył zgromadzonych, a nie dzielił.

Jeśli miałabym doszukiwać się słabości, mogłabym wypomnieć nietrzymanie się ram czasowych. Spotkanie zakończyło się ponad pół godziny później, niż planowano. Byłabym jednak niesprawiedliwa i niezgodna ze swoim sumieniem, gdybym uważała to za wadę. Przede wszystkim dlatego, że udział w konferencji był dobrowolny, każdy mógł wejść i wyjść, kiedy chciał, ale - co ważniejsze- wielokrotnie podczas naszego spotkania mówiliśmy o tym, że ludzie mają potrzebę bycia wysłuchani, i nie tylko dotyczy to bezdomnych, ale i każdego z nas. Przerywanie zatem mówiącym: „bo już późno”, byłoby zaprzeczeniem lekcji, jaką wówczas otrzymaliśmy. Szczerze mówiąc, była to pierwsza konferencja, w jakiej uczestniczyłam, na której nie przeszkadzano wykładowcom i wypowiadającym się, bo mówili dłużej niż było to w planie. Ogromny ukłon i wyraz szacunku dla organizatorów, którzy nie tylko słowem, ale przede wszystkim gestem, pokazali, jak ważny jest człowiek, jak cenna jest jego praca, wiedza i obecność. Ci wszyscy ludzie mówili do nas i dla nas, 
przyszli podzielić się z nami swoimi refleksjami i doświadczeniem, czemu mielibyśmy im zabronić dokończyć wypowiedź, kiedy wskazówki zegara są w innym miejscu niż było to w planach. Czas jest cenny, to prawda, ale dlatego należy wypełniać go tym, co wartościowe. A co ma większą wartość: szybszy powrót do domu czy cenna nauka o byciu człowiekiem? Każdy mógł wybrać, każdy mógł odpowiedzieć sobie sam. Mimo dobrowolnej obecności, kiedy nastąpił planowany czas zakończenia spotkania, nikt nie wyszedł z sali. Dla mnie to była najlepsza odpowiedź. Warto to docenić, zwłaszcza że organizatorzy byli na auli od samego rana, uczestniczyli we wszystkich etapach spotkania, czyli przez około trzynaście godzin, i mimo tego zmęczenia i świadomości, że jutro znów z samego rana pojawią się na auli, bez wątpliwości poświęcali swój czas w duchu wyższych wartości.

Drugi dzień miał charakter dyskusyjny. Ten dzień również mnie zaskoczył, był to zupełnie nowy wymiar spotkania, dotąd mi nieznany. Mimo wczesnej pory na auli pojawiło się sporo osób, co więcej, większość uczestniczyła we wczorajszej konferencji, co było najlepszym dowodem na to, że uczestnicy byli zadowoleni z przebiegu spotkania. Na początku zostały omówione sprawy formalne, z podkreśleniem, że każdy znajduje się tu dobrowolnie, a wybór sesji dyskusyjnej zależy tylko od nas - limitu miejsc nie było. Do wyboru było pięć spotkań tematycznych dotyczących: duchowości, tożsamości, przedsiębiorczości, filozofii oraz profilaktyki społecznej i promocji zdrowia. Profesor Kaszyński przedstawił wszystkich moderatorów spotkań oraz wskazał na miejsca, gdzie każda grupa odbędzie swoje. Ja wybrałam się na spotkanie dotyczące duchowości, które prowadzili ludzie, którzy zrobili wczoraj na mnie tak ogromne wrażenie, mianowicie brat Paweł Flis i profesor Tomasz Biernat. Nasza sesja dyskusyjna odbyła się na auli. Zgromadziła bardzo dużą grupę osób, zarówno studentów, jak i praktyków pracy socjalnej. Sesja była podzielona na dwie części, pierwsza - omawiająca duchowość od strony sacrum - prowadzona była przez brata Pawła, drugą - od strony profanum moderował profesor Biernat.

Zaczęliśmy od referatu brata Pawła. Mówił on o duchowości, w której centrum według chrześcijaństwa znajduje się Bóg. Odniósł się do Soboru Watykańskiego II, który mówił, że źródłami duchowości są: Słowo Boże, liturgia (Eucharystia) i wspólnota. Jak mówił brat Paweł, to chrzest otwiera nam drogę do duchowości. Wspominał także o jej aspektach czy etapach życia duchowego, podkreślając, że przemiana człowieka dokonuje się poprzez Boże działanie w nim. Po tej bardzo bogatej wypowiedzi nadszedł czas na pytania i refleksje. Brat Paweł pokazał się nam tu jako osoba bardzo ciepła, otwarta i szczera. Zgromadzeni słuchali go z przejęciem; jak zauważyłam, wiele osób notowało jego słowa. Ponownie, tak jak wczoraj, ludzie nie bali się mówić. Zabierali głos, wzajemnie się szanowali. Ciekawym momentem było to, że w chwili gdy pewna praktykantka pracy socjalnej zadała pytanie o duchowość u osoby uzależnionej, na sali pojawił się nie kto inny jak pan Wacław. Słychać było ogromny entuzjazm zgromadzonych, pan profesor Biernat mówił nawet o działaniu Ducha Świętego wiedzącego, w którym momencie zawołać do nas naszego wczorajszego gościa. Na sesji dyskusyjnej podejmowaliśmy wiele trudnych tematów, zastanawialiśmy się, czy każdy człowiek ma potrzebę życia 
duchowego, czy każdy tę duchowość posiada i czy życie wewnętrzne i duchowość są tym samym. Doszliśmy do wniosku, że duchowość jest nieuchwytna, trzeba się jej uczyć, praktykować ją, ale nigdy nie będziemy w stanie zamknąć jej w ramach pojęcia.

Po przerwie kawowej nadszedł czas na drugą część spotkania, czyli duchowość w wymiarze profanum. Po wstępie profesora Tomasza Biernata o tym, że duchowość można odnieść właściwie do każdej z dziedzin nauki i życia, nadeszły refleksje o tym, że o ile mówiąc o duchowości w wymiarze religijnym, można się pokusić o próbę zbudowania jednej jej definicji, o tyle z punktu widzenia społeczeństwa, abstrahując od Kościoła, tych definicji będzie mnóstwo. Pan Wacław powiedział, że: „duchowość to nie jest religijność, według niego „duchowość to realizowanie świata wartości”. Potem znów nadszedł czas na pytania i refleksje, było tu wiele ciekawych głosów i wniosków. Mówiliśmy o tym, jak ważne jest to, dlaczego decydujemy się zostać pracownikiem socjalnym, jaką mamy motywację, czy jest to pomoc drugiej osobie, czy pomoc sobie. Jeśli pomagamy innym, nasycamy swoją duszę wartościami, co buduje naszą duchowość. Musimy być jednak pokorni, jak powiedział pan Wacław, „pokora umie słuchać, pycha nie”. Profesor Biernat, podkreślił, że pomoc jest wynikiem zrozumienia, trzeba dotrzeć do czyjegoś wnętrza, do jego miłości i wydobyć ją. Jest to możliwe tylko wtedy, kiedy jesteśmy autentyczni. Doszliśmy do wniosku, że duchowość w pracy socjalnej wiąże się też z obowiązkiem pracy nad sobą. Myśli obecnych były tak ciekawe, że nim się obejrzeliśmy, nadszedł czas na drugą przerwę kawową, a po niej na zakończenie naszych obrad.

Kiedy spotkaliśmy się na auli po raz ostatni, zderzyły się dwie emocje: smutku, bo nasze spotkanie dobiega końca, ale i radości, bo mieliśmy poczucie bycia wewnętrznie ubogaconymi. Przedstawiciele każdej z grup dyskusyjnych streszczali przed zgromadzonymi to, o czym dyskutowali na swoich sesjach. Mówili o tym, nad czym się zastanawiali, co ustalili, a co zostało nierozstrzygnięte.

Po wszystkich wystąpieniach nadszedł czas na wnioski ogólne. Przytoczę jedynie kilka, które utkwiły mi w pamięci. Jednym z nich jest to, że trud pracy socjalnej polega na wyjściu ze swojej roli społecznej, na porzuceniu swojego tytułu. Trzeba odpowiedzieć sobie na pytanie - kim jestem najpierw? Czy pracownikiem socjalnym, magistrem, profesorem czy może człowiekiem? Tylko bycie w pierwszej kolejności człowiekiem jest gwarantem bycia dobrym pracownikiem socjalnym. Warto też pamiętać, że w swojej pracy musimy pracować na zasobach, a nie na deficytach. W każdej osobie musimy dostrzec pokłady możliwości, wydobyć je i wykorzystać w odbudowie poczucia wartości tej osoby w społeczeństwie. Musimy otworzyć się na drugiego człowieka i - jak powiedziała jedna ze studentek z Poznania, z którą miałam szczęście porozmawiać - „musimy go lubić”. To nasze nastawienie decyduje o tym, jak odbieramy ludzi wokół nas. Możemy im nie tylko pomóc, lecz także ich od tej pomocy odgrodzić. Patrząc na historię pana Wacława i pana Aleksandra, czułam wstyd, bo studiując w Krakowie, mijam bezdomnych bardzo często, z czasem przestałam zwracać na nich uwagę, traktować ich, nieładnie mówiąc, „jak element otoczenia”. Dziś wiem, że każdy z nas, jeśli znajdzie w sobie odrobinę odwagi i chęci, może działać. Ci wszyscy ludzie, którzy pomogli naszym gościom, niczym nie różnili się od nas. Więc co nas powstrzymuje od bycia człowiekiem? Przez ostatnie dziesięć 
sekund spotkania, w ciszy, cała sala patrzyła w oczy postaci z Portretu bezdomnego Jacka Hajnosa, znajdującej się na jednym z plakatów spotkania. Pan Aleksander powiedział, że widzi w nich smutek, samotność i potrzebę miłości. Każdy z nas mógł zadać sobie pytanie - co ja widzę w tych oczach?

Po zakończeniu naszego pięknego spotkania rozmawiałam $\mathrm{z}$ wieloma ludźmi, pytając o wrażenie i refleksje. Nie spotkałam się z żadną negatywną opinią. Rozmawiałam ze studentką z Ukrainy, z lekarką z Warszawy i z wieloma innymi osobami, które - tak jak ja - były pod ogromnym wrażeniem. Ktoś mógłby mnie oskarżyć o pisanie na zlecenie pozytywnej recenzji konferencji, czuję się jednak dobrze z tym, że tak nie było. Muszę przyznać, że kiedy dowiedziałam się, że jako absolwentka dziennikarstwa Uniwersytetu Papieskiego będę pisać relację z konferencji, miałam mieszane uczucia. Podeszłam do tego stereotypowo, tak jak pisałam na początku o studentach mających alergię na słowa „konferencja naukowa” - byłam jednym z nich. Teraz wiem, że zostałam „odczulona” i „odczarowana”. Jestem wdzięczna, nie dlatego, że mogłam napisać tę relację, ale dlatego, że mogłam wziąć udział w tak wspaniałym przedsięwzięciu. Choć piszę z perspektywy laika w pracy socjalnej, z którą dopiero zaczynam swoją przygodę. Dla mnie był to niesamowity start, konferencja dała mi motywację i zrodziła taką myśl, że chcę to robić. Za to jestem wdzięczna wszystkim, którzy pracowali nad przygotowaniem i realizacją konferencji.

Nie wyobrażam sobie nie wspomnieć o grupie studentów, która zrobiła na mnie bardzo pozytywne wrażenie, a mianowicie o studentach z Poznania. Przyjechali do nas w zasadzie „w ciemno”, zaufali jednej ze swoich wykładowczyń, którą znali bardzo krótko, a która zachęcała ich do przyjazdu do Krakowa. Myślę, że dziś nie żałują. Grupa ta była bardzo zgrana, wszyscy troszczyli się o siebie wzajemnie, było to widoczne, kiedy ktoś z nich źle się poczuł (a byłam świadkiem takiej sytuacji trzykrotnie) wszyscy poznańscy studenci bez wahania reagowali. Pierwszego dnia spotkania wypowiadała się jedna ze wspomnianych przeze mnie wcześniej studentek pracy socjalnej poznańskiego Uniwersytetu im. Adama Mickiewicza, Gosia Ciećmierowska. Zaimponowała mi - i jak sądzę, większości (jeżeli nie całej) sali zgromadzonych też mówiąc o tym, że na praktykach razem z koleżanką odmówiły wejścia do pokoi zamieszkiwanych przez bezdomnych, bo uznały, że jest to sfera prywatna i intymna tych ludzi, której one nie chciały zakłócać. To spojrzenie na drugiego jako na człowieka, a nie tylko na „bezdomnego”, wzruszyło mnie. Postanowiłam, że muszę zamienić z Gosią choć kilka słów. Następnego dnia udało nam się spotkać w małej salce i porozmawiać. Zapytałam ją o wrażenia po wczorajszym i dzisiejszym dniu, odpowiedziała:

Moje wrażenia są niesamowite, byłam już na kilku konferencjach i przepraszam, ale to były raczej paplaniny i gadanie, a tutaj jesteśmy jednak nastawieni na ten dialog. Na początku ta „filozofia spotkania” w ogóle mi to nie grało - praca socjalna, filozofia spotkania? Taki miałam zgrzyt (...), ale kiedy przyjechaliśmy i były te pierwsze wypowiedzi naszych bezdomnych, którzy teraz wyszli na prostą, to było takie niesamowite. Ta konferencja na pewno zostanie na dłużej w mojej pamięci i będzie takim motywem do refleksji. 
Kiedy zapytałam Gosię o to, co najbardziej zapamiętała, bez wahania odpowiedziała:

Jak dzisiaj profesor Czekaj mnie cytował, to było niesamowite. Jak wczoraj na końcu spotkania wypowiadałam się o tym, że trzeba lubić człowieka, bo ja taką filozofię wyznaję. Ja przyszłam na studia z powołania, mnie ta praca socjalna zawsze ciągnęła, zawsze jakieś wolontariaty, cuda-wianki - zawsze w tej pracy socjalnej siedziałam, choć może wtedy nie wiedziałam, że to jest praca socjalna. No i ja z tego wychodzę, że liczy się człowiek i gdzieś tam pokój na świecie. To jest takie moje motto przewodnie i to, co wczoraj powiedziałam, że trzeba być otwartym. I dzisiaj profesor Czekaj cytował mnie na naszej sesji dyskusyjnej, więc to było niesamowite i wtedy naprawdę poczułam się doceniona.

Na pytanie, czy warto uczestniczyć w takich konferencjach, odpowiedziała:

Tak, tak, tak i jeszcze raz tak. Najfajniejsza jest ta formuła braków zapisów na te sesje (...). Pierwszy raz spotykam się z taką formułą całkowicie luźną i atmosferą, gdzie niby jesteśmy na tych różnych poziomach, bo oni są profesorami, a my gdzieś tam dopiero studentami (...), a tutaj nie ma tego ewidentnego podziału, my słuchamy, ale też się wypowiadamy i jesteśmy słuchani. To jest najpiękniejsze.

Porozmawiałam także z jedną z organizatorek z grona studenckiego, Magdą Piekarczyk. Jak mówi:

W przygotowanie konferencji zaangażowałam się, ponieważ była to wspaniała okazja, aby stworzyć coś dobrego, oraz wyzwanie dla mnie jako studentki pracy socjalnej, które wiele mnie nauczyło. To jest niesamowite uczucie, kiedy człowiek staje się częścią zespołu i razem tworzy takie rzeczywistości, przestrzeń do dyskusji i spotkania. Nie wyobrażam sobie, że mogłabym się nie zaangażować.

Na moje pytanie, jak oceniłaby to, co było na konferencji w odniesieniu do założeń, odpowiedziała:

Dla mnie osobiście konferencja ta przerosła nasze oczekiwania. Stała się prawdziwym dziełem, które kosztowało nas wiele wysiłku i pracy. Patrząc na przebieg konferencji, widzę, że wszystko, co sobie zaplanowaliśmy, udało się wspaniale zrealizować. Siła tego wszystkiego tkwi w zespole, który stworzyliśmy. Jestem bardzo zadowolona z konferencji. (...) Na pewno nic bym nie zmieniła. Jedynie mogłabym rozwinąć i poszerzyć pewne aspekty. Widzę w tym nie potrzebę zmiany - bo wszystko się udało, ale wyzwanie na przyszłość, by budować coraz to nowsze rzeczy. Aby następne spotkania i konferencje, były jeszcze bardziej ubogacające dla mnie i każdego uczestnika.

\section{Swoją wypowiedź skwitowała słowami:}

Moim zdaniem konferencje takie jak ta są niezmiernie potrzebne. Nasza konferencja była szczególna, ponieważ po raz pierwszy spotkałam się z tego typu formą pracy oraz przebiegu konferencji. Niezwykłość tego zjawiska polegała na tym, że każdy wykład, sesja były przygotowywane poprzez 
spotkanie i budowane w tym duchu. Myślę, że my - jako studenci, praktycy, teoretycy - potrzebujemy takich spotkań jak ta konferencja, aby zatrzymać się nad tym, co tak naprawdę jest istotą naszej pracy. Spotkać i posłuchać ludzi z całej Polski oraz przekazywać sobie nawzajem cenne doświadczenia.

Podsumowując moją rozbudowaną relację, która z założenia miała być oddaniem moich emocji - jestem zadowolona. Konferencja Duszę dać trzeba. Praca socjalna wświetle filozofi spotkania może być bez wątpienia nazwana naukową, bo ona naprawdę tę funkcję nauczania spełniła. Wiele z niej wyniosłam i wiem, że każdy z obecnych także wziął coś dla siebie. Dziś czuję się zachęcona do udziału w konferencjach o tak złożonej, pięknej, ludzkiej tematyce. Takie spotkania są kopalnią, z której można wydobyć wiele cennych i praktycznych myśli. Jak wspomniałam, padało wiele słów, ale najważniejsze było to, że zarówno goście, jak i organizatorzy urzeczywistniali je swoim postępowaniem - szacunkiem, słuchaniem się nawzajem i próbą zrozumienia. Było to spotkanie na pewno uwrażliwiające, kłujące w duszę, którą przecież „trzeba dać”. 